\title{
Interference of age and repetition of the same noxious stimulus on hyperalgesia ${ }^{1}$
}

\author{
Jose F. Ibañez ${ }^{2 *}$, Irimar P. Posso ${ }^{3}$ and Verena Wallace ${ }^{4}$
}

\begin{abstract}
Ibañez J.F., Posso I.P. \& Wallace V. 2010. Interference of age and repetition of the same noxious stimulus on hyperalgesia. Pesquisa Veterinária Brasileira 30(9):777782. Departamento de Patologia Geral, Curso de Medicina Veterinária, Universidade Estadual do Norte do Paraná, Campus Luiz Meneghel, Rodovia BR 369 Km 54, Bandeirantes, PR 86360-000, Brazil. E-mail: ibanez@uenp.edu.br

Pain in animals has been recognized for less than one century. Several authors confirm that animals are capable to process, register and modulate nociceptive stimuli in a very similar way to human kind and there are several evidences registering the impact of pain sensation over vital systems interfering on disease outcome. Nevertheless, despite some evidences that animals, as human beings, can store information from past painful experiences less is known about how this so called pain memory works. The aims of this study were: to evaluate if the response to a painful stimuli differs during different stages of life and if repetition of a same acute stimuli in the same animal interferes with expression of hyperalgesia. Thus, 60 rats were selected and arranged in 3 equal groups: 3 months, 6 months, and 9 months of age. All animals were injected $5 \%$ formalin solution in the plantar face of hind paw under volatile general anesthesia. Von Frey filaments were applied at $1 \mathrm{~h}$, $24 \mathrm{~h}$ and $48 \mathrm{~h}$ after sensitization. Injection was repeated twice with a 30-day interval, each time in a different hind paw. Results showed that younger rats express lower hyperalgesia thresholds in the first stimulation compared to elder animals and that repetition of same stimulus diminishes hyperalgesia thresholds when it begins during infant period and augments hyperalgesia thresholds when it begins during elder ages.
\end{abstract}

INDEX TERMS: Rat, age, development, memory, allodynia, formalin test, algometer.

RESUMO.- [Interferência da idade e repetição do mesmo estímulo doloroso na hiperalgesia.] A dor nos animais tem sido reconhecida há pouco manos de um século. Vários autores reconhecem que os animais são capazes de processar, registrar e modular estímulos nociceptivos de modo muito similar aos seres humanos e há várias evidências registrando o impacto da sensação dolorosa sobre os sistemas vitais e curso da doença. Entretanto, a

\footnotetext{
${ }^{1}$ Received on March 10, 2009.

Accepted for publication on April 12, 2010.

2 Departamento de Patologia Geral, Curso de Medicina Veterinária, Universidade Estadual do Norte do Paraná, Campus Luiz Meneghel, Rodovia BR 369 Km 54, Bandeirantes, PR 86360-000, Brazil. *Corresponding author: ibanez@ffalm.br

${ }^{3}$ Faculdade de Medicina, Universidade de São Paulo (USP), Av. Dr. Arnaldo 455, São Paulo, SP 01246-903, Brazil. E-mail: irimar@terra.com.br

${ }^{4}$ Hospital Veterinário, Faculdade de Medicina Veterinária, Centro Universitário, Faculdades Metropolitanas Unidas, Rua Ministro Nelson Hungria 541, São Paulo, SP 05690-050. E-mail: ve.w@bol.com.br
}

despeito das evidências de que os animais, como os seres humanos, podem armazenar informações passadas de experiências dolorosas pouco se sabe sobre como a chamada memoria de dor funciona. Os objetivos deste estudo foram: avaliar se a resposta a um estímulo doloroso difere em diferentes fases da vida e se a repetição de um mesmo estímulo doloroso agudo no mesmo animal interfere na expressão da hiperalgesia. Assim, 60 ratos foram selecionados e agrupados em três grupos iguais: 3 meses, 6 meses e 9 meses. Foi injetada solução de formalina 5\% na face plantar de todos os animais durante anesthesia. $O$ limiar de hiperalgesia foi testado pelo método de filamentos de Von Frey à $1 \mathrm{~h}, 24 \mathrm{~h}$ e $48 \mathrm{~h}$ após a sensibilização. A injecão foi repetida duas vezes com intervalo de 30 dias, uma vez em cada membro. Os resultados demosntraram que animais mais jovens possuem limiares menores de hiperalgesia na primeira estimulação, comparados com os mais velhos e que a repetição de um mesmo estímulo doloroso agudo diminui o limiar de hiperalgesia quando o 
primeiro estímulo ocorre nas idades mais tenras e aumenta o limiar quando se inicia em idades mais avançadas.

TERMOS DE INDEXAÇÃO: Rato, idade, desenvolvimento, memória, alodinia, teste da formalina, algiometria.

\section{INTRODUCTION}

Several procedures in neonates and in veterinary practice are performed without any pain relief, due to the belief that nervous system is not completely mature right after birth. However, researches proved that newborns of several species are capable to identify noxious stimuli and that they interfere in maturation of sensitive pathways during central nervous system development (Ruda et al. 2000, Johnston \& Walker 2003). Apparently this occurs because during childhood central nervous system is prone to activity dependent modulation (Homaister et al. 2009, Walker et al. 2009).

Nociceptive stimulus can evoke major alterations in medullar function, including sensitization. Recently, several authors have purposed detailed theories of how nociceptive stimuli modify central nervous system (Zelter et al. 1997, Al-Chaer et al. 2000, Ruda et al. 2000, Bhutta et al. 2001, Melzak et al. 2001). Although it's known that precocious stimuli modulates sensitive pathways and response to pain later, the amount of injured tissue necessary to modulate such alterations is to discuss (Walker et al. 2009).

Not only after birth, but later during infancy, stimuli can alter neuronal perception of pain. In a study evaluating pain threshold in children aging from 9 to 16 years old and burned from 6 to 24 months of age, authors could confirm that they had lower thresholds compared to children that had never burned their selves (Wollgarten-Hadamk et al. 2009).

Perception of pain is complex and includes psychological and sensorial information that are liable to psychological factors. Children of different ages may experience the same painful stimulus, however, due to differences on development of the ability to graduate and report stimuli or other pain components, responses may vary largely (Goodenough et al. 1999, Al-Chaer et al. 2000). Some authors postulate that children and adults may see pain as a stress and functional disability generator. These stimuli applied frequently and intensively during development may lead to a belief that pain is threatening and this may trigger a defense response and lower the ability to cope with it (Hohmeister et al. 2009).

Postoperatory pain simulation in laboratory animals include, among others, plantar incision, developed by Brennan et al (1996), and formalin test, presented by Dubuisson \& Dennis (1977). Formalin tests have been used to simulate postoperatory inflammatory component and presents two phases: phase I with peak at 5 minutes mediated by local sensitive fibers; and phase II, about 15 minutes after injection, mediated by inflammatory mediators and non noxious sensitive fibers (Bhutta et al. 2001, Hogan 2002, Ashmawi et al 2003).

Quantifying hyperalgesia evolves behavioral patterns and devices capable to translate them into numbers. One of these is the von Frey filament set, largely used to measure hyperalgesia (Brenan et al. 1996, Hogan 2002, Ririe et al. 2004).
Recognize, qualify and quantify pain in animals is of essential importance to provide them welfare and in consequence, to humans, once the similarity between sensitive pathways and nociceptive responses in both life kinds (Hogan 2002). It's well known that children submitted to painful stimuli during childhood express less coping ability and tolerance to pain stimuli latter in life (Hohmeister et al. 2009).

An important point is to evaluate the importance of considering the age of animals undergoing pain research protocols, since it may alter behavior and pain thresholds depending on the life stage experiments are proceeded (AlChaer 2000, Ririe et al. 2004).

Thus, the aims of this study were to investigate if age interferes in the expression of hyperalgesia after a noxious stimulation, and if repetition of the same noxious stimulus in the same individual interferes on expression of hyperalgesia.

\section{MATERIALS AND METHODS}

Sixty Wistar male rats with light period control and ad libitum water and food were used. Experimental protocol was approved by Research Ethical Analysis Committee of Hospital das Clínicas and Medicine School, Universidade de São Paulo, on April 25, 2002, under protocol number 246/02.

Animals were divided into three groups $(n=20): 3$ months (GF3), 6 months (GF6) and 9 months of age (GF9).

Sensitization was gained by administering $0.05 \mathrm{ml}$ of $5 \%$ formalin solution with an insulin syringe and a $20 \times 5.5 \mathrm{G}$ needle in the subcutaneous plantar face of hind paw (Fig.1).

To perform injection animals were anesthetized with halothane ${ }^{5}$ in $100 \%$ oxygen. After injection animals were identified and devolved to their respective boxes.

Withadraw threshold was measured with von Frey filaments ${ }^{6}$ as suggested by Brennan et al (1996). Each filament, in a crescent order was applied three consecutive times with a 3 to 5 seconds interval and if no response was observed, another filament was tested. Positive response was considered when tested animal lifted sensitized paw. When animals' paws were

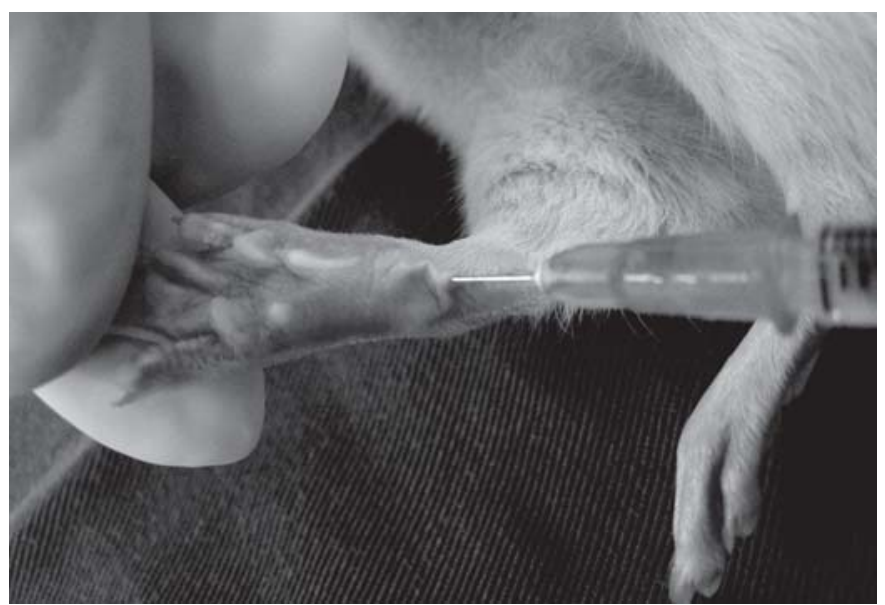

Fig.1. Hind paw with needle, pointing the site of injection.

\footnotetext{
${ }^{5}$ Fluothane ${ }^{\mathrm{TM}}$, Astra Zeneca do Brasil Ltda, Rodovia Raposo Tavares, Km 26.9, Cotia, São Paulo, SP 06707-000.

6 Touch Test Sensory Evaluator Kit ${ }^{\mathrm{TM}}$, Stoelting, 620 Wheat Lane, Wood Dale, Illinois 60191, USA.
} 


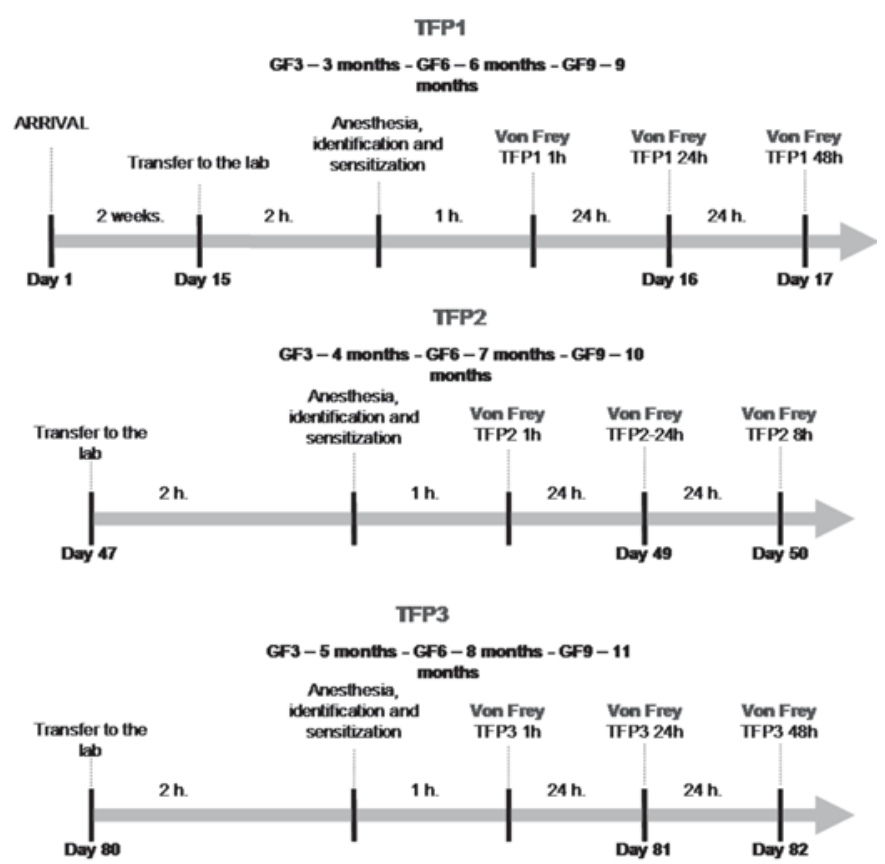

Fig.2. Experimental design illustrating the moments of sensitization and pain tests. TFP, Plantar formalin test (injection of).

already lifted before testing, value attributed was zero, meaning that it was already in pain.

To perform von Frey test, animals were put in a translucid plastic box with a wire mesh floor through which filaments were applied by indirect vision with a mirror.

Sensitization was performed three times (T1, T2 and T3), with a 30 day interval in each group, so that GF3 was tested at 3, 4 and 5 months old; GF6 at 6, 7 and 8 months old and GF9 at 9,10 and 11 months old. Hyperalgesia was measured at $1 \mathrm{~h}$, 24h and 48 after each sensitization (Fig.2).

Kruskall-Wallis test was applied to compare data among groups, repetition and moment. In order to verify which groups showed different means, Mann-Whitney test was performed.

To compare means of data among repetitions during different moments and groups we used Friedman test, repeated to each data set (each repetition).

Global 5\% significance level vas controlled with Bonferroni method.

\section{RESULTS}

After first sensitization, $100 \%$ of GF9 animals presented limb lameness $1 \mathrm{~h}$ after stimulus against $85 \%$ of animals in GF3 and $35 \%$ of animals in GF6. Limb lameness was observed in $100 \%$ of animals $1 \mathrm{~h}$ after second and third sensitization.

GF3, GF6 and GF9 had different thresholds in moments T1 - 1h; T1 - 24h; T1 - 48h, T2 - 48h; T3 - 24h, and T3 - 48h (Table 1).

Mann-Whitney analysis revealed that except during T124h when GF3 presented higher thresholds, in all other moments of T1 and all moments of T2 and T3, animals in GF3 presented lower thresholds compared to GF6 and GF9 although sometimes differences were numerical, with no statistical significance (Table 2, Fig.3).

Group GF3 showed higher thresholds in T1-24 compared to T3-24h, and although not statistically significant, T2-24h showed intermediary values between T1-24h and T3-24h, suggesting a decreasing pattern in hyperalgesia threshold along repetition of stimuli for GF3 group 24h after sensitization. Group GF9 behaved in an inverse mode, with

Table 1. Descriptive levels (alpha) for Kruskal-Wallis analysis of T1, T2, T3 ( $p=$ 0.05). 2004

\begin{tabular}{ccc}
\hline Test & Moment & $\mathrm{p}$ value \\
\hline T1 & $1 \mathrm{~h}$ & 0.001 \\
& $24 \mathrm{~h}$ & 0.001 \\
& $48 \mathrm{~h}$ & 0.001 \\
T2 & $1 \mathrm{~h}$ & $\mathrm{x}^{*}$ \\
& $24 \mathrm{~h}$ & 0.402 \\
& $48 \mathrm{~h}$ & 0.020 \\
T3 & $1 \mathrm{~h}$ & $\mathrm{x}$ \\
& $24 \mathrm{~h}$ & 0.008 \\
& $48 \mathrm{~h}$ & 0.001 \\
* Zero values. & \\
\hline \multirow{2}{*}{ Zero }
\end{tabular}

Table 2. Descriptive levels (alpha) to Mann-Whitney test comparing hiperalgesia among GF3, GF6 and GF9. Means \pm standard errors $(p=0.05)$

\begin{tabular}{|c|c|c|c|c|}
\hline \multirow{2}{*}{$\begin{array}{r}\text { Test } \\
\text { T1 }\end{array}$} & \multirow{3}{*}{$\begin{array}{c}\text { Moment } \\
1 \mathrm{~h}\end{array}$} & \multicolumn{2}{|c|}{ Values von Frey filaments $(\mathrm{mN})$} & $\begin{array}{l}\text { Descriptive } \\
\text { level (alpha }\end{array}$ \\
\hline & & GF3-2,6 $\pm 1,5 \mathrm{mN}$ & GF6-17,5 $\pm 6,6 \mathrm{mN}$ & 0.003 \\
\hline & & GF3-2,6 $\pm 1,5 \mathrm{mN}$ & GF9-0,0 mN & \\
\hline & & GF6-17,5 $\pm 6,6 \mathrm{mN}$ & GF9-0,0 mN & $-x-{ }^{*}$ \\
\hline & $24 \mathrm{~h}$ & GF3-159 $\pm 27,9 \mathrm{mN}$ & GF6-35,6 $\pm 9,3 \mathrm{mN}$ & 0.001 \\
\hline & & GF3-159 $\pm 27,9 \mathrm{mN}$ & GF9-31,2 $\pm 3,4 \mathrm{mN}$ & 0.002 \\
\hline & & GF6-35,6 $\pm 9,3 \mathrm{mN}$ & GF9-31,2 $\pm 3,4 \mathrm{mN}$ & 0.190 \\
\hline & $48 \mathrm{~h}$ & GF3-25,2 $\pm 4,7 \mathrm{mN}$ & GF6- $63,1 \pm 13,9 \mathrm{mN}$ & 0.001 \\
\hline & & GF3-25,2 $\pm 4,7 \mathrm{mN}$ & GF9-70,6 $\pm 5,4 \mathrm{mN}$ & $<0.001$ \\
\hline & & GF6-63,1 $13,9 \mathrm{mN}$ & GF9-70,6 $\pm 5,4 \mathrm{mN}$ & 0.063 \\
\hline T2 & $48 \mathrm{~h}$ & GF3-51,7 $\pm 8,6 \mathrm{mN}$ & GF6-75,3 $3 \pm 9,4 \mathrm{mN}$ & 0.029 \\
\hline & & GF3-51,7 $\pm 8,6 \mathrm{mN}$ & GF9-132,1 $\pm 25,9 \mathrm{mN}$ & 0.012 \\
\hline & & GF6-75,3 $\pm 9,4 \mathrm{mN}$ & GF9-132,1 $125,9 \mathrm{mN}$ & 0.426 \\
\hline T3 & $24 \mathrm{~h}$ & GF3-33,3 $\pm 5,8 \mathrm{mN}$ & GF6-65,3 $\pm 19,7 \mathrm{mN}$ & 0.210 \\
\hline & & GF3-33,3 $\pm 5,8 \mathrm{mN}$ & GF9-91,3 $\pm 20,9 \mathrm{mN}$ & 0.002 \\
\hline & & GF6-65,3 $\pm 19,7 \mathrm{mN}$ & GF9-91,3 $\pm 20,9 \mathrm{mN}$ & 0.087 \\
\hline & $48 \mathrm{~h}$ & GF3-29,6 $\pm 3,2 \mathrm{mN}$ & GF6-124,5 $\pm 28,6 \mathrm{mN}$ & 0.009 \\
\hline & & GF3-29,6 $\pm 3,2 \mathrm{mN}$ & GF9-128,9 $\pm 25,9 \mathrm{mN}$ & $V<0.001$ \\
\hline & & GF6-124,5 $\pm 28,6 \mathrm{mN}$ & GF9-128,9 $925,9 \mathrm{mN}$ & V 0.421 \\
\hline
\end{tabular}

* Values equal zero. Values expressed by mean \pm pattern error. Bold values $(p<0.05)$

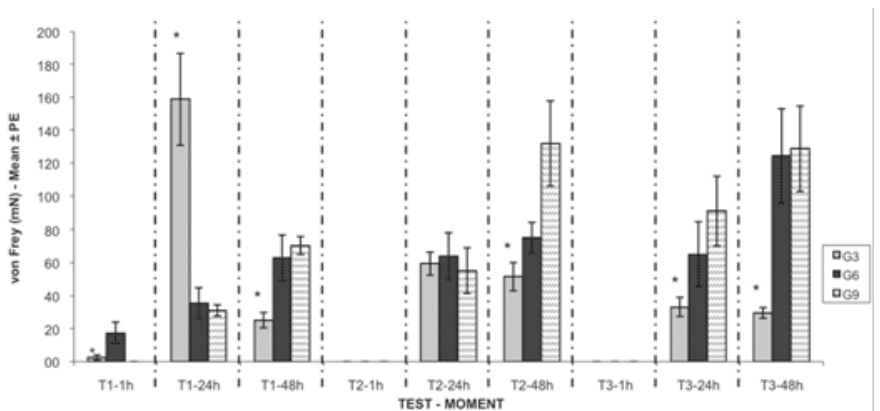

Fig.3. Comparison of means \pm standard errors of force eliciting hyperalgesia with von Frey test. Means \pm standard errors; * $\mathrm{p}<0.0167$. G3=GF3, G6=GF6, and G9=GF9. 

Table 3. Descriptive levels for Friedman test comparing hiperalgesia thresholds among repetition (TFP1, TFP2 e TFP3) in different groups and moments. Means \pm standard errors $(p=0.05) .2004$

\begin{tabular}{|c|c|c|c|c|c|}
\hline Moment & Group & T1 & T2 & T3 & $\begin{array}{c}\text { Descriptive level } \\
\text { (alpha) }\end{array}$ \\
\hline & GF3 & $2,6 \pm 1,5 \mathrm{mN}$ & 0,0 & 0,0 & 0.500 \\
\hline \multirow[t]{2}{*}{$1 \mathrm{~h}$} & GF6 & $17,5 \pm 6,6 \mathrm{mN}^{\dagger}$ & 0,0 & 0,0 & $<0.001$ \\
\hline & GF9 & 0,0 & 0,0 & 0,0 & $x^{*}$ \\
\hline \multirow[t]{3}{*}{$24 \mathrm{~h}$} & GF3 & $159,0 \pm 27,9 \mathrm{mN} \dagger$ & $59,6 \pm 7,0 \mathrm{mN}$ & $33,3 \pm 5,8 \mathrm{mN} \dagger$ & 0.006 \\
\hline & GF6 & $35,6 \pm 9,3 \mathrm{mN}$ & $64,2 \pm 14,2 \mathrm{mN}$ & $65,3 \pm 19,7 \mathrm{mN}$ & 0.054 \\
\hline & GF9 & $31,2 \pm 3,4 \mathrm{mN} \dagger$ & $55,4 \pm 13,9 \mathrm{mN}$ & $91,3 \pm 20,9 \mathrm{mN} \dagger$ & 0.008 \\
\hline \multirow[t]{3}{*}{$48 \mathrm{~h}$} & GF3 & $25,2 \pm 4,7 \mathrm{mN} \dagger$ & $51,7 \pm 8,6 \mathrm{mN}^{\dagger}$ & $29,6 \pm 3,2 \mathrm{mN}$ & 0.016 \\
\hline & GF6 & $63,1 \pm 13,9 \mathrm{mN}$ & $75,3 \pm 9,4 \mathrm{mN}$ & $124,5 \pm 28,6 \mathrm{mN}$ & 0.776 \\
\hline & GF9 & $70,6 \pm 5,4 \mathrm{mN}$ & $132,1 \pm 25,9 \mathrm{mN}$ & $128,9 \pm 25,9 \mathrm{mN}$ & 0.534 \\
\hline
\end{tabular}

* Zero. $\dagger$ statistically significant difference $(p<0.05)$.

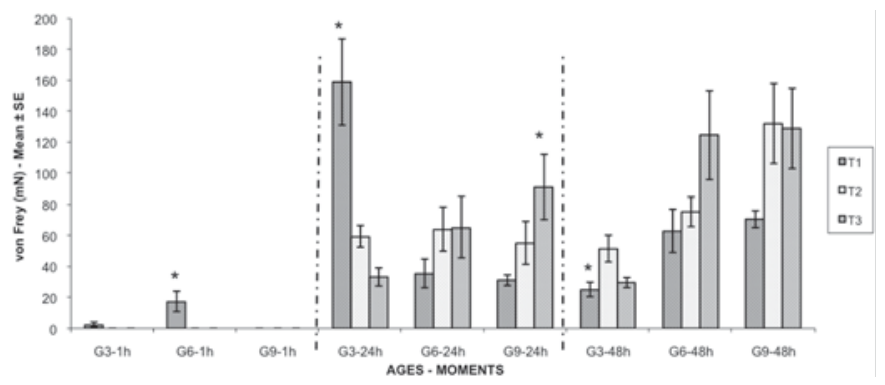

Fig.4. Comparison of means \pm standard errors of hiperalgesia threshold among repetitions at $1 \mathrm{~h}, 24 \mathrm{~h}$ and $48 \mathrm{~h}$ after sensitization in groups GF3, GF6, and GF9. * $p<0.0167$. G3=GF3, G6=GF6, and G9=GF9.

T1-24h presenting statistically inferior values than obtained in T3-24h and T2-24h with values numerically intermediary between T1-24h and T3-24h, suggesting an increase in hyperalgesia threshold along repetition of stimuli to GF9 group.

Group GF6 did not show statistical differences among T124h, T2-24h and T3-24h, nevertheless, T1-24h, T2-24h and T3-24h followed the same crescent pattern observed in GF9

The same observations were seen in groups GF6 and GF9 in moments T1-48h, T2-48h and T3-48h, when data presented the same crescent pattern, without statistical differences however. A higher hyperalgesia threshold was observed in group GF3 in T2-48h compared to T1-48h and lowering to values similar to T1-48h in moment T3-48h, always with no statistical significance (Table 3, Fig.4).

\section{DISCUSSION}

Once personal report is not a reliable option with very young children and animals, pain treatment tends to occur on what is expected. However, if subject doesn't act as expected, behavior can be misinterpreted as non painful. It may be difficult to differ pain from anxiety when stress behavior is present. When submitted to acute pain, either stress or pain are combined and exteriorized by behavior (Zeltzer et al. 1997, Hogan 2002). This could explain the lower hyperalgesia thresholds observed in GF3 group 1 hour after sensitizations, compared to GF6 and GF9.

Stimuli pattern and intensity, as well as time interval and duration of discharges on afferent fibers are imperative to hype- ralgesia induction and long time synaptic alterations. Nevertheless, frequency used to evoke these kinds of responses in experimental models is infrequent in nature (Sandküler \& Liu 1998, Ririe et al. 2004, Hohmeister et al. 2009).

A large number of hiperalgesia models are based on inflammatory pain produced by inflammatory mediators and peripheral nervous cells in the lesion area, that sensitize primary afferent fibers diminishing depolarization threshold and producing alodinia and hyperalgesia (McKenna \& Melzack 2001, Ashmawi et al 2003, Johnston \& Walker 2003). The amount of damaged tissue necessary to result in nervous long lasting pathways modification is controverse (Camozzato et al. 2009, Walker et al. 2009). Less intense stimuli may lead to long term activation of wide range neurons even during physiological conditions and this may be an induced afferent hyperalgesia mechanism and could justify the decrease in hyperalgesia threshold in group GF3 during subsequent sensitizations compared to previous ones (Rygh et al. 1999, Johnston \& Walker 2003).

It seems that phase I of formalin test occurs by direct nociceptor stimulation, mainly $C$ fibers, and mediators involved in each of two phases are also different: $P$ substance in phase I and histamine, serotonin, prostaglandins and bradikinine during phase II. Phase II depends on dorsal horn stimulation during phase I. It's believed that histamine may facilitate afferent medullar pathways (Ashmawi et al. 2003)

In the present study sensitivity differences were observed among the age groups, with GF3 showing lower hyperalgesia thresholds than GF6 or GF9, which accords to Grunnau et al. (2001) and Johnston \& Walker (2003) who postulated that the way stimuli are processed after first occurrence during immature periods of nervous system, may be different, inducing hyperalgesia. Hohmeister et al. (2009) also postulate that infant can barely deal with unpredicted or suddenly events.

Viganó et al. (1998), affirm that mechanical sensitivity thresholds augment with age, however their studies were performed in non previously sensitized individuals. Nevertheless, animals from group GF9 were the only ones showing limb impotence $1 \mathrm{~h}$ after sensitization and rats from group GF6 presented lower thresholds than GF3, disa- 
greeing with the referred authors, but in accordance to Turk et al. (1995) who affirm that the elder individuals are more sensitive to pain.

In a study comparing needle puncture sensitivity in children aging from 7 to 11 years, and 12 to 16 years, younger ones presented lower thresholds than elder ones (Goodenough et al. 1999). In an other study with children undergoing venipuncture and divided in groups that received previous anesthetic block, placebo and no kind of prevention, authors showed age difference with younger children more sensitive, and a strong positive correlation between anxiety and high predictive pain scores (Goodenough et al. 1997).

Pain may not always be related to intensity of trauma or disease, but it must be related also to environmental, emotional and evolutive factors, as previous experiences and the way parents contribute to interpretation of painful stimuli and resulting stress (Gibson 2004, Hohmeister et al. 2009).

Endogenous antinociceptive mechanisms may be activated by environmental stimuli such as battle fields, races, sexual acting or even by individual motivation when adapted do some condition (Sudhakar \& Venkatesh 2003, Camozzato et al. 2009, Walker et al. 2009). Perhaps, inexperience to handling and the unknown conditions of the first stimulation may have evoked these antinociceptive mechanisms in GF3 animals, increasing their pain threshold as observed in T1-1h and T1-24h and in T-1h for GF6 ones. Emotions such as fear and anxiety may interfere on pain intensity and quality. Stress induced analgesia may also be observed in large trauma victims. In rats it has been found that c-fos expression diminishes when a painful stimulus is applied during stressful conditions (Magalhães 2003)

There are some suppositions that repeated stimuli in the same place may develop altered disseminated responses during pain perception (Oberlander et al. 2000, Gibson 2004, Camozzatto et al. 2009).

Prolonged exposition to some stimulus models show that some kinds of injury lead to permanent structural and functional alterations, besides to central nervous system reorganizing with neural connection altered patterns (Grunau 1998, Capone \& Aloisi 2004).

In our findings, GF3 animals presented lowering thresholds when stimuli was repeated, mainly $24 \mathrm{~h}$ after sensitization; and GF6 and GF9 animals showed an inverse behavior, with increasing thresholds during repetition of stimulus. Perhaps there is more susceptibility of sensitive changes depending to acute stimuli as the ones produced by formalin in infant ages.

Sandkuler \& Liu (1998) affirmed that information processing in dorsal horn can be changed by long periods. An intense neuron stimulation which is typical of extense trauma or inflammation is followed by exacerbated nociceptive response behavior. It's believed that this kind of hyperalgesia is mediated either by nociceptor sensitization as by dorsal horn neuroplastic changes.

Younger children are more anxious, expect more pain and have more affective pain than older ones. In a study evaluating anxiety to venipuncture authors observed that anxiety was directly related to prior experiences. Although the possibilities of biological factors interfere on sensitivity during infancy, researches on pain in children suggest that children that report greatest pain intensity may not have reached enough developmental status to let them see the purpose of pain situation or to generate any dealing strategy with pain. This explanation can justify high anxiety degree influencing pain expectance (Lander \& Fowler-Kerry 1991, Capone \& Aloisi 2004).

It's impossible to register pain report in animals as well as their emotional discomfort; however it's possible to estimate that anxiety by repetition of a same acute and intense stimulus in a period which memory has been poorly fed (GF3) due to short time living produced more vigorous responses with lower pain thresholds, in the same way that the idea that capability to deal with uncomfortable events modifies pain reaction (Lander \& Fowler-Kerry 1991, Goodenough et al. 1999, Al-Chaer et al. 2000, Hohmeister et al. 2009).

Another important point is pain tolerance, related do individual's capability to support a stimulus. Although pain perception is uniform among healthy individuals, affective fraction of pain varies largely. This suggests that previous knowledge as well as pain situation interferes with its affective response or tolerance (Ririe et al. 2004, Walker et al. 2009).

Affective quality of tonic pain experimentally applied in human beings is more comparable to chronic pain than to phasic pain, what makes phasic pain tests most indicated to acute pain studies (Lavriere \& Melzack 1996, Souza et al. 2008).

In contrast, the test used in this study produced a persistent tissue injury involving different neuronal pathways as well as pharmacological ways, reproducing clinical pain with fidelity and permitting subjects to deal with pain and contributing to memory formation (Souza et al. 2008).

Results and observations on the present study lead to a rethink of other studies about sensitivity performed with animals of age and life periods unknown. There is influence of these variables and previous noxious exposition in hyperalgesia expression.

\section{CONCLUSIONS}

Younger animals showed decreasing pattern on hyperalgesia thresholds when the same noxious stimulus was repeated.

Older animals showed an increasing pattern on hyperalgesia thresholds when the same noxious stimulus was repeated.

Formalin test applied during first third life in rats may be capable to modify pain sensitivity for long periods.

\section{REFERENCES}

Al-Chaer E.D., Kawasaki M. \& Pasricha P.J.A. 2000. New model of chronic visceral hypersensitivity in adult rats induced by colon irritation during postnatal development. Gastroenterology 119(5):1276-1285 
Aloisi A.M., Ceccarelli I., Fiorenzani P., De Padova A.M. \& Massafra C. 2004. Testosterone affects formalin-induced responses differently in male and female rats. Nerurosci Lett. 361:262-264.

Ashmawi H.A., Chambergo F.S., Palmeira C.C.A. \& Posso I. 2003. The effects of pyrilamine and cimetidine on mRNA expression and nociceptive flinching behavior in rats. Anest. Analg. 97:541-546.

Bhutta A.T., Rovnaghi C., Simpson P.M., Gossett J.M., Scalzo F.M. \& Anand K.J.S. 2001. Interactions of inflammatory pain and morphine in infant rats: long-term behavioral effects Phys. Behavior 73:5158 ,

Brennan T.J., Vandermeulen E.P. \& Gebhart G.F. 1996. Characterization of a rat model of incisional pain. Pain 64:493-501.

Camozzato T.S.C., Winkelmann-Duarte E.C., Padilha C.B., Miguel S.P.R., Bonzanini L., Anselmo-Franci J.A., Fernandes M.C. \& Lucion A.B. 2009. Neonatal handling reduces the number of cells in the medial preoptic area of female rats. Brain Res. 1247:92-99.

Capone F. \& Aloisi A.M. 2004. Refinement of pain evaluation techniques: The formalin test. Ann. 1st Super Sanità 40:223-229.

Dubuisson D. \& Dennis S.G. 1977. The formalin test: A quantitative study of the analgesic effects of morphine, meperidine and brain stem stimulation in rats and cats. Pain 4:161-174.

Gibson S.J. 2004. A review of age differences in the neurophysiology of nociception and the perceptual experience of pain. Clin. J. Pain 20:227-239.

Goodenough B., Kampel L., Champion G.D., Laubreaux L. \& Nicholas M.K. 1997. An investigation of the placebo effect and age-related factors in the report of needle pain from venipuncture in children. Pain 72:383391.

Goodenough B., Thomas W., Champion D.D., Perrot D., Taplin J.E., Baeyer C.L.von \& Ziegler J.B. 1999. Unravelling age effects and sex differences in needle pain: Ratings of sensory intensity and unpleasantness of venipuncture pain by children and their parents. Pain 80:179-190.

Grunau R.E. 1998. Children's judgements about pain at age 8-10 years of extremely low birth weight $(\leq 1000 \mathrm{~g})$ : Children differ from full birth weight peers? J. Child. Psychol. Psychiatry 39:587-594.

Hogan Q. 2002. Animal pain models. Reg. An. Pain Med. 27:385-401.

Hohmeister J., Demirakça S., Zohsel K., Flor H. \& Hermann C. 2009. Responses to pain in school-aged children with experience in a neonatal intensive care unit: Cognitive aspects and maternal inuences. Eur. J. Pain 13:94-101.

Johnston C.C. \& Walker C.D. 2003. The effects of exposure to repeated minor pain during the neonatal period on formalin pain behaviour and thermal withadrawal latencies. Pain Res. Manag. 8:213-217.

Lander J. \& Fowler-Kerry S. 1991. Age differences in children's pain. Percept. Mot. Skills 73:415-418.
Lavriere W.R. \& Melzack R. 1996. The bee venom test: A new tonicpain test. Pain 66:271-277.

Magalhães C.M.N. 2003. Choque hemorrágico controlado e expressão da proteína Fos em medula espinhal de ratos após estímulo nociceptivo periférico. Tese de Doutorado, USP, São Paulo. 98p.

Mckenna J.E. \& Melzack R. 2001. Blocking NMDA receptors in the hippocampal dentate gyrus with AP5 produces analgesia in the formalin pain test. Exp. Neurol. 172:92-99.

Oberlander T.F., Grunau R.E., Whitfield M.F., Fitzgerald C., Pitfield S. \& Saul J.P. 2000. Biobihavioral pain responses in former extremely low birth weight infants at four months'corrected age. Pediatrics 105:1-10.

Ririe D.G., Barclay D., Prout H., Tong C., Tobin J.R. \& Eisenach J.C. 2004. Preoperative sciatic nerve block decreases mechanical allodinya more in young rats: Is preemptive analgesia developmentally modulated? Anesth. Analg. 99:140-145.

Ruda M.A., Ling Q., Hohmann A.G., Peng Y.B. \& Tachibana T. 2000. Altered nociceptive neuronal circuits after neonatal peripheral inflammation. Science 289:628-630.

Rygh L.J., Svendsen F., Hole K. \& Tjolsen A. 1999. Natural noxious stimulation can induce long-term increase of spinal nociceptive responses. Pain 82:305-310.

Sandküler J. \& Liu X. 1998. Induction of long-term potenciation at spinal synapses by noxious stimulation or nerve injury. Eur. J. Neurosci. 10:2476-2480.

Souza A.M., Franco P.A.B., Ashmawi H.A. \& Posso I.P. 2008. Efeito analgésico local do Tramadol em modelo de dor provocada por Formalina em ratos. Revta Bras. Anest. 58:372-379.

Sudhakar H.H. \& Venkatesh D. 2003. Gender differences in predator induced pain perception in rats. Indian J. Exp. Biol. 41:270-272.

Turk D.C., Okifuji A. \& Scharff L. 1995. Chronic pain and depression: Role of perceived impact and perceived control in different age cohorts. Pain 61:93-101.

Viganó A., Bruera E. \& Suarez-Almazor M.E. 1998. Age pain intensity and opioid dose in patients with advanced cancer. Cancer. 83:12441250.

Walker S.M., Franck L.S., Fitzgerald M., Myles J., Stocks J. \& Marlow N. 2009. Long-term impact of neonatal intensive care and surgery on somatosensory perception in children born extremely preterm. Pain 141:79-87.

Wollgarten-Hadamek I., Hohmeister J., Demirakça S., Zohsel K., Flor H. \& Hermann C. 2009. Do burn injuries during infancy affect pain and sensory sensitivity in later childhood? Pain 141:165-172.

Zeltzer L.K., Bush J.P., Chen E. \& Riveral A. 1997. A psychobiological approach to pediatric pain: Part I. History physiology and assessment strategies. Curr. Probl. Pediatr. 6:225-253. 